\title{
BÖHMEN UND DIE EIGENKIRCHEN: ZU DEN ELITEN DES FRÜHEN MITTELALTERS BIS DIE MITTE DES 12. JAHRHUNDERTS
}

\author{
TOMÁŠ VELÍMSKÝ \\ Philosophische Fakultät, Jan-Evangelista-Purkyně-Universität Ústí nad Labem \\ E-mail: tomas.velimsky@ujep.cz
}

\begin{abstract}
Bohemia and the Proprietary Churches. A Note to the Elites of the Early Middle Ages till the Half of the 12th Century

The phenomena of the proprietary churches is connected with the very beginnings of the Christianity in Moravia and later in Bohemia, too. The founders of the churches of the period of the 9th and 10th century were - as attested by the sources - only the members of Mojmirid and Přemyslid dynasty, the rank of Slavník who founded the church in Libice is still a matter of discusion. From the 11th century on, the increasing number of documents tells us that the other members of elites - magnates or majors - founded their churches. The founders and their posterity definitely had a considerable influence on the function of these churches, appointed priests and decided or co-decided how the incomes of the churches will be used. The conclusion, that by this only their economical interests were served, is however to be rejected. The founders not only strengthened their prestige, but they were also motivated by their belief and hope for salvation. Since the half of the 12th century the number of proprietary churches increased rapidly, the members of the elite (retinues) holding now the hereditary lands started to settle on their properties and built late-romanesque churches next to the court residences. This phase of development (until the end of the phenomena of the proprietary churches during the emancipation of the Bohemian church in the first third of the 13th century) is however not a part of this paper. Keywords: proprietary church; Bohemia; Catholic church; Christianization; elites
\end{abstract}

Im Jahre 471 ließ der romanisierte gotische Großmächtige Flavius Valila (er war nicht einmal Arianer wie die meisten Goten, sondern Christ nach dem römischen Ritus), ein Mann im Dienst des späteren Kaisertums, comes et magister militae, auf seinem Besitz in der Örtlichkeit Massa Cornutiana, nicht weit von der kaiserlichen Residenz Tivoli in Latium eine Kirche bauen. Die Kirche Santa Maria di Cornuto überlebte bis in die Neuzeit, sie wurde im 18. Jahrhundert abgerissen. Es blieb aber die Abschrift der berühmten Urkunde erhalten, die als Charta Cornutiana ${ }^{1}$ bezeichnet wird, aus der hervorgeht, dass Valila auf die Kirche einen ausgedehnten Grundbesitz aus seinem Eigentum übertrug, dessen Erträge den Betrieb und die Wartung des Heiligtums sichern sollten (es wurden hauptsächlich die Kosten für das Leuchten hervorgehoben), sie sollten aber auch den Lebensunterhalt der Priester, die dort wirkten, bestreiten. Der Bestandteil der Spende

1 Der Text der Urkunde ist zugänglich durch die Edition Liber pontificalis. Bd. 1, hg. von Louis DUCHESNE. Paris 1886, S. CXLVI ff. 
war der an die Kirche anliegende Hof, dessen Bebauung den Klerikern und weiteren Kirchendienern, die als custodes bezeichnet wurden, zum Wohnen dienen sollte. Zur Zierde der Kirche wurden zahlreiche Stücke aus Edelmetall (de argenti), liturgische Gegenstände und Handschriften bestimmt. Die Stiftung verband Valila mit der folgenden verbindlichen Bedingung: Niemand, weder Bischof noch Priester und andere Personen, durfte aus dem Kirchenbesitz etwas veräußern, für andere Zwecke verwenden oder auf andere Subjekte übertragen. Falls es trotzdem zur Verletzung dieser Verordnung käme, behielt Valila für sich sowie seine Nachkommen und Erben das Recht vor, das gespendete Eigentum wieder zurückzufordern. Die Verordnung garantierte also sowohl Valila als auch seinen Nachfolgern deutlich „in alle Ewigkeit“ die volle Kontrolle über den Kirchenbesitz. Somit hingegen unterdrückte er die Kompetenzen des Bischofs, d.h. der Kirche, die ohne Zustimmung des weltlichen Inhabers vom Kirchengebäude nicht entscheiden durfte. Deshalb wird das angeführte Beispiel für einen der frühesten Belege der Entstehung des Phänomens der sog. Eigenkirchen gehalten, das die Entwicklung des Christentums in den folgenden mehr als sieben Jahrhunderten beeinflusste ${ }^{2}$.

Zum Aufbau der ersten christlichen Kirchen auf böhmischem Gebiet - abgesehen vom unsicheren Fall des entdeckten Grundrisses des Holzbaus in der Anlage von Kněživka bei Tuchoměřice, der hypothetisch als arianisches Kirchlein interpretiert wurde ${ }^{3}-$ kam es an der Wende des 8. und 9. Jahrhunderts im Milieu des sich konstituierenden frühen mährischen Staates. Soweit es erhaltene schriftliche Quellen erfassen, waren die Fürsten die ersten Erbauer der großmährischen Kirchen. Das gilt von Pribina, der zuerst die Kirche in Nitra und später im Jahre 850 auch die Kirche in Blatnograd/Zalavár erbauen ließ ${ }^{4}$. Auch sein Sohn Kocel ließ in der Nähe von Blatnograd - auf dem Ort, genannt Ortah - die Michaeliskirche bauen. Sie wurde vom salzburgischen Erzbischof Adalwin am 1. Januar 865 eingeweiht. Schon um einen Tag früher weihte der Erzbischof irgendwo in der Nähe, auf den Besitztümern eines gewissen Vitimír (Wittimar), die Stephanskirche ein. Der Großmächtige Vitimír wurde schon im Jahre 850 in der Umgebung von Pribina erwähnt und die Kirche wird mit der Lokalität Getye-Szentistván, circa 15 Kilometer nördlich von Blatnograd verbunden. Conversio führt für die Jahre 865 und 866 an, dass Adalwin im Kocels Plattenseer Fürstentum noch weitere zehn Kirchen einweihte. Ihre Lokalisierung ist aber sehr problematisch und noch dazu war die Situation auf diesem Gebiet, das für mehrere Jahrzehnte ein Teil der fränkisch-pannonischen Mark bildete, sicher spezi-

2 Ulrich STUTZ, Geschichte des kirchlichen Benefizialwesens von seinen Anfängen bis auf die Zeit Alexanders III. Berlin 1895, S. 53-55; Hans Heinrich Feine, Studien zum langobardisch-italischen Eigenkirchenrecht, in: Ulrich Stutz - Hans Erich FEINE (Hgg.), Forschungen zu Recht und Geschichte der Eigenkirche. Aalen 1989, S. 1-4 (ursprünglich als Studien zum langobardisch-italischen Eigenkirchenrecht. Teil 1, in: Zeitschrift der Savigny-Stiftung für Rechtsgeschichte, Kanonistische Abteilung 30 (1941), S. 1-4); Susan WOOD, The Proprietary Church in the Medieval West. Oxford 2006, S. 12-13. Aus einer anderen Sicht Carla SFAMENI, Ville residenziali nell'Italia tardoantica. Bari 2007, S. 270.

3 Eduard DROBERJAR, Věk barbarů: české země a stěhování národů z pohledu archeologie. Praha/Litomyšl 2005, S. 42-44.

4 Aufgrund der Unverfügbarkeit zitiere ich nicht aus der neuesten Edition Conversio Bagoariorum et Carantanorum, hg. von Fritz LOŠEK. Hannover 1997, sondern benutze ich die alte Edition De conversio Bagoariorum et Carantanorum libellus. hg. von Wilhelm WATTENBACH, in: MGH Scriptores (in Folio). Bd. 11: Historiae aevi Salici. Hannover 1854, S. 11-12. Siehe auch: Dušan TŘEŠTÍK, Vznik Velké Moravy. Praha 2001, S. 112-115. 
fisch ${ }^{5}$. Für Mähren selbst fehlen jegliche konkrete Belege von den Kirchengründern, man kann nur annehmen, dass die Hauptrolle die Fürsten aus der Dynastie der Mojmiriden spielten. Im Fall einiger Kirchen außerhalb des Umfangs der Burgstätten, z. B. in der Siedlungsagglomeration in Mikulčice, ist auch die Initiative der Großmächtigen bei der Gründung von Eigenkirchen anzunehmen ${ }^{6}$.

Wenn wir uns in Böhmen der Přemysliden-Zeit umsehen, dann bringen die Eigenkirchen betreffenden legendenartigen Quellen des 9. und 10. Jahrhunderts Informationen ausschließlich von den Eigenkirchen, die von den Fürsten auf den Burgstätten erbaut wurden. Christians Legende enthält die Nachricht über die Clemenskirche in Levý Hradec, die der Fürst Bořivoj gründete, nachdem er in Mähren vom Erzbischof Method getauft worden ist ${ }^{7}$. Die Marienkirche auf der Prager Burg sollte Bořivoj gründen, nachdem er aus seiner mährischen, vom Fürsten Strojmír verursachten, Verbannung nach Böhmen wieder zurückgekehrt worden war ${ }^{8}$. Die altslawische Prologslegende von der heiligen Ludmila fasst zusammen, dass Bořivoj gemeinsam mit Ludmila die Kirchen erbauten und Geistliche versammelten ${ }^{9}$. Auch die jüngere böhmische Redaktion der Legende Crescente fide verbindet Bořivoj mit den Anfängen des böhmischen Christentums ${ }^{10}$, obwohl sie ähnlich wie die ältere bayerische Redaktion - aus begreiflichen Gründen die Verbindung mit dem Großmährischen Reich verschweigt und den Ausbau der Marienkirche auf der Prager Burg und einer anderen Petruskirche (meinte damit der Autor der Legende die Kirche in Budeč?) erst dem Fürsten Spytihněv I. zuschreibt ${ }^{11}$. Die Angaben der bayerischen Redaktion der Legende Crescente fide übernimmt auch Gumpolds Legende ${ }^{12}$. Christians Legende schreibt ausdrücklich die Erbauung der Petruskirche auf der Burg Budeč Spytihněv I. zu ${ }^{13}$, den Fürsten Vratislav I. bezeichnen die Legenden wiederholt als Gründer der Georgskirche auf der Prager Burg14. Die Ludmila-Legende Fuit in pro-

5 De conversio, S. 14. Siehe auch Zdeněk MĚříNSKÝ, České země od příchodu Slovanů po Velkou Moravu. Bd. 2. Praha 2006, S. 679-681.

6 Z. b. Vladimír VAVŘÍNEK, Velká Morava mezi Byzancí a latinským Západem, in: Luděk Galuška Pavel Kouřil - Zdeněk Měřínský (Hgg.), Velká Morava mezi Východem a Západem: sborník příspěvků z mezinárodní vědecké konference, Uherské Hradiště, Staré Město 28. 9. - 1. 10. 1999. Brno 2001, S. 413-419.

7 Legenda Christiani. Vita et passio sancti Wenceslai et sancte Ludmile ave eius, hg. von Jaroslav LUDVÍKOVSKÝ. Praha 1978, S. 20.

8 Legenda Christiani, S. 24. Zur Problematik der archäologischen Aufdeckung der Marienkirche vgl. Ivan BORKOVSKÝ, Kostel Panny Marie na Pražském hradě, in: Památky archeologické 44 (1953), S. 129-198; seine Resultate revidierte Jan FROLÍK, Kostel Panny Marie, in: Jan Frolík - Jana Maříková-Kubková (Hgg.), Nejstarši sakrální architektura Pražského hradu: výpověd’ archeologických pramenů. Praha 2000, S. 17-95.

9 Proložní legenda o sv. Ludmile (Život sv. Lidmily), hg. von Josef KOLÁ̌̌, in: Fontes rerum bohemicarum. Bd 1. Praha 1873, S. 123.

10 Passio s. Vencezlai incipiens verbis Crescente fide christiana. Recensio bohemica, hg. von Jaroslav LUDVÍKOVSKÝ, in: Ders., Nově zjištěný rukopis legendy Crescente fide a jeho význam pro datování Kristiána, in: Listy filologické 81 (1958), S. 56-67, hier S. 58.

11 Crescente fide Christiana. Recensio bavarica, hg. von Josef EMLER. Fontes rerum bohemicarum. Bd. 1, S. 183.

12 Gumpoldi Mantuani episcopi Passio sancti Vencezlai martyris, hg. von Josef EMLER. Fontes rerum bohemicarum. Bd. 1, S. 148.

13 Legenda Christiani, S. 28. Zur archäologischen Forschung der St. Peter-Kirche in Budeč vgl. Miloš ŠOLLE, Rotunda sv. Petra a Pavla na Budči, in: Památky archeologické 81 (1990), S. 140-207.

14 Beide Redaktionen Crescente fide: Fontes rerum bohemicarum. Bd. 1, S. 183; Ludvíkovský, S. 58; Legenda Christiani, S. 28; Gumpoldi Mantuani episcopi Passio, S. 148. 
vincia Boemorum und Christian unterrichten einstimmig davon, dass Vratislavs Witwe Drahomíra auf dem Grab der ermordeten Schwiegermutter Ludmila in der Burg Tetín die Michaeli-Basilika bauen ließ, um so den Ursprung der Wunder zu verdecken, die sich hier abspielten ${ }^{15}$. Vom heiligen Wenzel berichtet die sog. Erste altslawische Legende, dass er sehr gut (oder schön) die Kirchen in allen Burgen angelegt hat ${ }^{16}$ und danach erwähnen alle Legenden, deren Ursprung bis ins 10. Jahrhundert reicht, ausdrücklich die Gründung der Veitskirche auf der Prager Burg17. Wichtige Rolle spielt in den Legenden auch die Kirche auf der Burg Stará Boleslav/Altbunzlau. Während die Legenden Crescente fide und Gumpolds Legende Boleslavs Sitz nur unbestimmt ohne nähere Lokalisierung erwähnen, gehen die erste altslawische Legende und Christian davon aus, dass Wenzels Ermordung auf der Burg in Boleslav verlief und berichten, dass hier Wenzel zur Messe am Feiertag der heiligen Cosmas und Damian kam, denen nach Christian die hiesige Kirche eingeweiht war ${ }^{18}$.

Über die Rolle Boleslavs I. bei Kirchengründungen schweigen die Legenden und der Chronist Cosmas schreibt mit Berufung auf ein gewisses Privileg des Georgsstiftes die Gründung von zwanzig Kirchen erst seinem Sohn Boleslav II. zu ${ }^{19}$. Er führt auch an, dass der erste Prager Bischof Thietmar die Kirchen weihte, die von den Gläubigen an mehreren Orten errichtet wurden ${ }^{20}$, woraus man schlussfolgern kann, dass auch weitere Personen aus dem Kreis der Gefolgseliten Gründer der Kirchen waren. Man darf aber nicht vergessen, dass Cosmas' Nachricht schon aus der Zeit um eineinhalb Jahrhundert später stammt, sodass sie wahrscheinlich seine eigenen Vorstellungen widerspiegelt, die auf unterschiedlichen geschichtlichen Tatsachen des angefangenen 12. Jahrhunderts beruhen.

Näher der Realität des 10. Jahrhunderts stehen die ältesten Adalbertslegenden, also die sog. Canaparius' Legende ${ }^{21}$ und die Legende des Bruno von Querfurt. In den beiden findet man die Erwähnung der Kirche auf dem Sitz Vojtěchs/Adalberts Vater Slavník, wohin die Eltern ihren schwerkranken Sohn brachten, ihn auf den Marienaltar legten und dem Gottesdienst widmeten ${ }^{22}$. Während die Existenz der Kirche auf der Burgakropol in

15 Fuit in provincia Boemorum, hg. von Václav CHALOUPECKÝ, Prameny 10. století Legendy Kristiánovy o sv. Václavu a sv. Ludmile. Praha 1939, S. 478; Legenda Christiani, S. 42.

16 První staroslověnská legenda o sv. Václavu, übereinstimmend in allen Redaktionen: der Novljaner Text der kroatisch-glagolischen Redaktion, die Vostokovs Legende und der Text der russischen Redaktionen. Siehe Josef Vajs, Sborník staroslovanských literárních památek o sv. Václavu a sv. Lidmile. Praha 1929.

17 Nur der Text der sog. Menäeren Redaktion der ersten altslawischen Legende spricht hier von der Kirche des heiligen Abraams (Emmerams?). Die Kirche wurde am Fest des heiligen Emmerams, Patrons von Regensburg, eingeweiht.

${ }_{18}$ Legenda Christiani, S. 64.

19 Die Chronik der Böhmen des Cosmas von Prag (Cosmae Pragensis Chronica Boemorum) (MGH Scriptores rerum Germanicarum. Nova series. Bd. 2), hg. von Berthold BRETZHOLZ. Berlin 1923, S. 42 (I 22).

20 Die Chronik der Böhmen, S. 46 (I 24).

${ }^{21}$ In der Gegenwart wird Canaparius' Urheberschaft skeptisch genommen, als Autor kommt der Bischof Notger aus Lüttich oder eher jemand aus seiner Umgebung in Erwägung: vgl. Johannes FRIED, Gnesen - Aachen - Rom: Otto III. und der Kult des hl. Adalbert: Beobachtungen zum älteren Adalbertsleben, in: Michael Borgolte (Hg.), Polen und Deutschland vor 1000 Jahren: die Berliner Tagung über den „Akt von Gnesen“. Berlin 2002, S. 235-279; auch Dušan TŘEŠTíK, Proč byli vyvražděni Slavníkovci?, in: Vojtěch Vaněk - Jiří K. Kroupa (Hgg.), Slavníkovci v českých dějinách. Praha 2006, S. 14.

22 Jana Kanaparia Život svatého Vojtěcha, hg. von Josef EMLER, in: Fontes rerum bohemicarum. Bd. 1, S. 236; Bruno z Querfurtu, Život svatého Vojtěcha, hg. u. übers. von Marie KYRALOVÁ. Praha 1996, S. 14 . 
Libice mit der archäologischen Forschung bestätigt wurde ${ }^{23}$, bleibt die Datierung der Johanniskirche in Malín ${ }^{24}$ oder der Wenzelskirche in Vrbčany ${ }^{25}$ in den weiteren Orten der vermutlichen Slavníks Herrschaft unsicher. Auch im Fall der Wenzelskirche in Žabonosy in der Nähe von Vrbčany bestätigte aktuell Jan Frolíks Forschung die Existenz der romanischen Emporkirche aus der zweiten Hälfte des 12. Jahrhunderts, welche der Bau der dreischiffigen Basilika vorging. Ihre Datierung bleibt jedoch unsicher und bis jetzt es ist nicht ausgeschlossen, dass es möglich wäre, von ihrer Entstehung schon im Zeitraum des 10. Jahrhunderts nachzudenken ${ }^{26}$.

Mit der Aussage der Adalbertslegenden wird auch die Burg in Starý Plzenec oder sogar die dortige Petri-Rotunde verbunden ${ }^{27}$. Das ist aber schon ein Interpretationsergebnis: der Name der Burg, die Adalbert bei der Rückkehr aus Rom nach Böhmen besuchte, führen die Legenden nicht an und auch über die Kirche gibt es keine unmittelbare Erwähnung. Die Legenden schildern nur Adalberts Ernüchterung aus der Wirklichkeit, dass hier am Sonntag ein Markt stattfand, was den christlichen Grundsätzen widersprach ${ }^{28}$.

Die archäologische Forschung trug zur Entdeckung der Rotundenüberreste in der Lage der Burg in Staré Brno bei, deren Gründung mit der Beherrschung Mährens von Přemysliden verbunden ist. Die Entstehung der Rotunde, die später durch den Bau der romanischen einschiffigen Marienkirche abgewechselt wurde, ist archäologisch nur grob in die Zeit vom Ende des 10. bis zum Anfang des 11. Jahrhunderts zu datieren ${ }^{29}$.

Mit der bewegten Krisenzeit des böhmischen Staates um die Jahrtausendwende ist die Relation Thietmars von Merseburg verbunden, der den Feldzug des Heinrichs II. nach Böhmen im Jahre 1004 beschrieb. Als ihm die Ortsbewohner die Burgtore in Saaz (Žatec)

23 Rudolf TUREK, Libice, knižecí hradisko 10. věku. Praha 1966-1968.

24 Eine kritische Zusammenfassung aller bekannten Angaben zuletzt Karel KIBIC ml. - Filip VELÍMSKÝ, Př́íspěvek ke stavební historii kostela sv. Jana Křtitele v Malíně. Stavební vývoj, výsledky archeologického průzkumu, in: Průzkumy památek 15/1 (2008), S. 127-135.

25 Diese von Vojtěch Budinský-Krička durchgeführte Forschung in den Jahren 1935-36 entdeckte die Relikte der romanischen Tribunkirche aus der zweiten Hälfte des 12. Jahrhunderts. Diesem Bau ging jedoch eine ältere einschiffige Kirche vor, die für Gründung des Bischofs Adalbert vom Ende des 10. Jahrhunderts gehalten wurde. Vgl. Václav WAGNER, Kostel ve Vrbčanech, in: Jan Květ - Oldřich Blažíček (Hgg.), Cestami umění. Praha 1949, S. 48; Rudolf TUREK, Čechy na úsvitě dějin. Praha 1963, S. 224 f. Neulich wurde es in Frage gestellt, sieh Petr SOMMER - Vojtěch VANĚK, Existe-t-il une architecture Slavníkienne?, in: Vaněk - Kroupa (Hgg.), Slavníkovci v českých dějinách, S. 20-34.

26 Eine von den Apsiden der älteren Kirche wurde schon durch die Forschung von Vojtěch BudinskýKrička im Jahre 1937 aufgedeckt, als Überrest Slavníks Kirche hat sie wieder bezeichnet TUREK, Čechy na úsvitě dějin, S. 224 f. Die aktuellen Forschungsergebnisse vgl. Soňa HENDRYCHOVÁ - Jan FROLÍK, Kostel sv. Václava v Žabonosech (okres Kolín) a jeho počátky, in: Archaeologia historica 41/1 (2016), S. 229-240.

27 Die Existenz der Petri-Rotunde am Ende des 10. Jahrhunderts wird allgemein angenommen. Anežka MERHAUTOVÁ - Dušan TŘEŠTÍK, Románské umění v Čechách a na Moravě. Praha 1983, S. 39 f. akzeptieren es mit einigen Vorbehalten, denn es gibt kein zuverlässiger Beweis von der Entstehungszeit der Rotunde. Ohne größeren Zweifel Klára BENEŠOVSKÁ, Deset století architektury. Bd. 1: Architektura románská. Praha 2001, S. 94.

28 Die Episode kennt Bruno von Querfurt, Život svatého Vojtěcha [Vita sancti Adalberti], S. 58-61, aber ohne Ortsangabe. Plzeň erwähnt erst der Text Verše o utrpení svatého Vojtěcha [Versus de passione sancti Adalberti], in: Fontes rerum bohemicarum. Bd. 1, hg. von Josef EMLER, S. 325, dessen Entstehung zum Ende des 11. Jahrhunderts datiert wird: Jana NECHUTOVÁ, Latinská literatura českého středověku do roku 1400. Praha 2000, S. 55 ff.; Rostislav Nový - Jiří Sláma - Jana Zachová (Hgg.), Slavníkovci ve středověkém písemnictví. Praha 1987.

29 Dana CEJNKOVÁ, Archeologický výzkum ve starobrněnském klášteře, in: Forum Brunense: sborník prací Muzea města Brna. Brno 1992, S. 11-20. 
öffneten und als es zur Ermordung der Kämpfer der polnischen Besatzung von Bolesław dem Tapferen kam, ließ der Herrscher die übrig gebliebenen in eine Kirche führen ${ }^{30}$.

Herrschersgründungen waren auch die ersten böhmischen Klöster. Über die Gründung des Klosters der Benediktinerinnen bei der Georgskirche auf der Prager Burg, dessen erste Äbtissin die Tochter von Boleslav I. Mlada/Marie wurde, informiert sowohl der Chronist Cosmas, als auch die angebliche Urkunde des Papstes Jan XIII., die zwar das spätere Falsum aus dem 11. Jahrhundert ist, inhaltlich ist sie jedoch glaubwürdig ${ }^{31}$. Der Herzog Boleslav II. gründete im Jahre 993 auf die Anregung des Bischofs Adalbert das Benediktinerkloster in Břevnov ${ }^{32}$, aufgrund des letzten Willens dieses Herrschers gründete dann sein Sohn Boleslav III. im Jahre 999 oder 1000 das Kloster in Ostrov ${ }^{33}$.

Auch die Entstehung des Prager Bistums war die Sache des Herrschers und der erste Prager Bischof Dietmar war vor allem Herzogskaplan. Cosmas behauptet, dass den Bischofszehnten schon der erste Prager Bischof Dietmar anordnete, er führt jedoch an, dass erst der Bischof Ekkehard, der sein Amt in den Jahren 1018-1023 unter Regierung des Herzogs Oldřich bekleidete, die Art des Einzugs von Zehnten veränderte. Cosmas' Angabe bezieht sich wahrscheinlich auf den gesamten kirchlichen Zehnten, mit dem bis zum Anfang des 13. Jahrhunderts die Kirchenbesitzer wirtschafteten. Sie entschieden darüber, wieviel Mittel sie wirklich für den Betrieb und die Wartung der Kirchen, für die Versicherung der Kleriker und für die Unterstützung der Armen und Bedürftigen auszugaben und was im Gegenteil für ihren eigenen Gewinn blieb. Es wurde nur die Abführung des eigenständig eingehobenen Bischofszehnten in der Höhe von sechs Denaren verbindlich ${ }^{34}$.

Ekkerhards Vorgänger Thiddag bekleidete das Bischofsamt in der bewegten Krisenperiode des böhmischen Staats an der Jahrtausendwende. Auch er war vor allem Diener der regierenden Fürsten, von denen sechs im Laufe seiner Wirkungszeit am Fürstenstuhl saßen. Dem Fürsten Boleslav II. diente er v. a. als Leibarzt. Aufgrund der Erwähnungen in der Chronik des Thietmar von Merseburg ${ }^{35}$ beschrieb der tschechische Historiker Václav Novotný vor mehr als einem Jahrhundert Thiddags Wirkung in der kurzen Regierungszeit des Fürsten Vladivoj mit diesen scharfen Worten ... der Fürst ständig betrunken, der Bischof selten nüchtern ${ }^{36}$. Thietmar entschuldigte allerding Bischofs Trinken mit seiner

30 Thietmari Merseburgensis episcopi Chronicon (MGH Scriptores rerum Germanicarum. Nova series. Bd. 9), hg. von Robert HOLTZMANN. Berlin 1935, S. 288 (VI 11).

31 Die Chronik der Böhmen, S. 42 f. (I 22); Codex diplomaticus et epistolarius Regni Bohemiae. Bd. 1, hg. von Gustav FRIEDRICH. Praha 1907, S. 342-343 (Nr. 371).

32 Dazu zwei urkundliche Falsa aus dem 13. Jahrhundert, von denen das erste teilweise von der wirklichen päpstlichen Urkunde von Johann XV. ausging, das zweite dann die Schenkung des Gründers Boleslav II., bestätigen sollte: Codex diplomaticus et epistolarius Regni Bohemiae. Bd. 1, S. $43-46$ (Nr. 38), S. 347-350 (Nr. 375). Zur umfangreichen Literatur zuletzt Josef ŽEMLIČKA, K hodnověrnosti listiny Jana XV. pro klášter v Břevnově (31. V. 993), in: Ivan Hlaváček - Marie Bláhová (Hgg.), Milénium břevnovského kláštera (993-1993). Praha 1993, S. 25-39; Jiří PRAŽÁK, Privilegium pervetustum Boleslai, ebd., S. 13-24.

33 Die Schenkung des Klosters von Boleslav III. beschreibt die Konfirmation des Königs Přemysl Otakar I. aus dem Jahre 1205 (tatsächlich noch etwas jüngeres Falsum) - vgl. Codex diplomaticus et epistolarius Regni Bohemiae. Bd. 1, S. 46-47 (Nr. 40), a Codex diplomaticus et epistolarius Regni Bohemiae. Bd. 2, hg. von Gustav FRIEDRICH. Praha 1912, S. 379-383 (Nr. 359).

34 Die Chronik der Böhmen, S. 75 f. (I 40). Dazu Pavel BOLINA, Příspěvek k interpretaci Kosmových desátkových údajů, in: $\check{C} \breve{C H} 103$ (2005), S. 828-860.

35 Thietmari Chronicon, S. 291 (VI 12) und S. 468 ff. (VII 56).

36 Václav NOVOTNÝ, České dějiny. Bd. 1. Teil 1. Praha 1912, S. 675. 
Krankheit, es sollte ihm schweres Händezittern mildern, an welches er litt. Der Chronist vergaß zugleich nicht, auch Thiddags Verdienste zu erwähnen.

Im Zeitraum der Anfänge des böhmischen Přemyslidenstaates im 10. Jahrhundert ist also die Beteiligung der Großmächtigen, Vordermänner und anderer Gefolgseliten an der Gründung der Eigenkirchen nicht zu beweisen, man weiß auch nicht viel über die Vermögenslage der Gefolgsleute. Die Fürstin Ludmila sollte nach Christians Legende die Vorderleute Tunna und Gommon, die auf Tetín kamen, um sie zu ermorden, so ansprechen: erinnert ihr euch nicht daran, wie ich euch mit Gold, Silber und prachtvollen Bekleidung beschenkt habe?37 Von dieser Anrede kann man darauf schließen, dass ihr Dienst dem Fürsten die Grundlage für die Stellung der Gefolgsleute war. Der Fürst kümmerte sich hingegen um ihre materielle Absicherung ${ }^{38}$. Die Erste altslawische Legende erwähnt den Hof des Vordermanns Hněvsa, in dem die Verschworenen in der Nacht zusammenkamen, um die Ermordung des Herzogs Wenzel vorzubereiten ${ }^{39}$. Der Hof befand sich entweder direkt im Burgareal oder in seiner Nähe. Ob dieser Hof als Hněvsas Eigentum zu bezeichnen ist, oder wurde er ihm nur vom Fürst Boleslav zur Nutzung für die Zeit der Ausübung seiner Funktion überlassen (als Fürstenvordermann konnte er Boleslavs Burg verwalten), davon sagt die Quelle nichts aus. Christians Legende beschreibt dann, wie Wenzels Dienstmann Podiven nach der Rückkehr aus Verbannung nach Böhmen die Wohnung eines Mannes aufsuchte, von dem er wusste, dass er der Kopf einer Verschwörung gegen den Herzog Wenzel und einer von seinen Mördern war. Er fand ihn im Dampfbad, das man in der Volkssprache stuba nennt, und ermordete $\mathrm{ihn}^{40}$. Das Bad stellte meistens ein selbstständiges Objekt dar und aufgrund dessen ist also zu schließen, dass sich Christians Bezeichnung domus wahrscheinlich auf den ganzen Wohnkomplex bezieht. Es ist jedoch schwer zu sagen, ob es um einen umzäunten Hof ging (Podiven konnte nämlich problemlos rein und wieder raus gehen). Es ist also offenkundig, dass sich die Interpretation auch hier wieder auf unsicherem Boden bewegt.

Die tschechische Archäologie trug zu den Kenntnissen über das Aussehen der Höfe der Großmächtigen in den Burgen oder ihres Hinterlandes nur wenig bei. Die Zusammenfassungen von Zdeněk Váňa über die Existenz des Hofes auf der Burg Budeč wurden in Zweifel gestellt ${ }^{41}$. Wichtige Ergebnisse brachte die archäologische Erforschung der Burgstätte in Saaz. Auf ihrer Akropolis entstand ein Herrscherhof mit dem Holzpalastbau vielleicht schon am Ende des 10. Jahrhunderts und in seiner Nähe kann man auch ein Sakralobjekt vermuten, vielleicht die in den Quellen später erwähnte Petrikirche, in deren

37 Legenda Christiani, S. 37.

38 So besonders Dušan TŘEŠTíK, Počátky Přemyslovců: vstup Čechů do dějin (530-935). Praha 1997. Siehe auch die immer verlaufende Diskussion zu diesem Thema: zuletzt Josef ŽEMLIČKA, O „svobodné soukromosti“ pozemkového vlastnictví (K rozsahu a kvalitě velmožské držby v přemyslovských Čechách), in: ČCH 107 (2009), S. 269-308. Zu den gegensätzlichen Ansichten, die die Frage der Kontinuität des privaten Vermögensbesitzes im ganzen Frühaltertum behandeln, neulich Martin WIHODA, Přemyslovská medievistika o sobě a sobě, in: ČMM 128 (2009), S. 447-460; Libor JAN, Hereditas, výsluha, kastelánie, ebd., S. 461-472.

39 První staroslověnská legenda o sv. Václavu, siehe Fußnote 16.

40 Legenda Christiani, S. 86.

41 Zdeněk VÁŇA, Přemyslovská Budeč: archeologický výzkum hradiště v letech 1972-1986. Praha 1995; seine Vorstellungen stellte gerechterweise in Zweifel Andrea BARTOŠKOVÁ, Dvorec hradského správce na Budči?: srovnání publikovaných závěrů s výpovědí terénní dokumentace, in: Archeologické rozhledy 56/2 (2004), S. 310-320. 
Nähe sich die Minoriten in der hochmittelalterlichen Stadt niederließen ${ }^{42}$. Am Anfang des 11. Jahrhunderts wurde ein weiterer Hof in der befestigten Vorburg bei der Veitskirche aufgebaut, der als Sitz des Burgverwalters dienen konnte. Durch diese Forschung ist es gelungen, den Grundriss der romanischen einschiffigen Kirche mit dem anliegenden Friedhof und mit den Spuren der Umzäunung des Hofes zu entdecken. Die Forschung brachte leider keine weiteren Erkenntnisse zur bewohnbaren Bebauung dieses Hofes ${ }^{43}$.

Die Frage der Funktion des Hofes auf der befestigten Vorburg von Saaz hängt ohne Zweifel mit der Relation der Chronik des Domherrn Cosmas zusammen, der zum Jahre 1061 die Geschichte des Burgverwalters Mstiš aus Bílina, des Sohnes von Bor, einschrieb. Mstiš diente ursprünglich im Jahre 1055 als Kastellan in Lštění, wo er auf Befehl des Herzogs Spytihněv II. die Ehefrau Herrschers Bruder Vratislav gefangen hielt. Er führte sich so auf, dass es für die verheiratete Frau kompromittierend war und er missachtete damit auch ihren Ehemann. Erst auf die Fürbitte des Bischofs Šebiřr/Severus wurde die schwangere Frau freigelassen, aber auf dem Weg zu ihrem Ehemann hatte sie eine Fehlgeburt und sie ist gestorben ${ }^{44}$. Als Spytihněv II. verstarb und Vratislav II. zum regierenden Herzog wurde, musste der nach Bílina beförderte Mstiš um seine Stellung Angst haben. Hinter seinem Versuch sich mit dem Herzog zu versöhnen, stand wahrscheinlich wieder der Bischof Šebír als Vermittler. Mstiš lud den Herzog nach Bílina zur festlichen Weihe der Petrikirche ein, die er dank dem freundlichen Entgegenkommen des gestorbenen Herzogs Spytihněv (wie er selbst hervorhob) in der Vorburg (in suburbio) bauen ließ. Vratislav sagte seine Teilnahme zu und kam wirklich zur Weihe der Kirche in Bílina ${ }^{45}$. Nach dem festlichen, von dem Bischof zelebrierten Gottesdienst stürzte sich das Szenario der Versöhnung (die Messe, Festessen, Versöhnungsritual mit der Erteilung des Friedenskusses) zusammen. Vor der Kirche nahm der Herzog die Einladung zum Festessen im Hof von Mstiš nicht an und begab sich mit seinem Gefolge in die Burg hinauf. Bei Mstiš sind nur der Bischof und vermutlich nicht viele Freunde geblieben. Danach brachte ein Bote aus der Burg die Nachricht, dass der Herzog Mstiš von seinem Amt enthob und anstatt ihn Kojata, V̌̌ebors Sohn, ernannte, der zu „dieser Zeit der Erste auf dem Fürstenhof " war. Mstiš reagierte nach Cosmas mit der folgenden berühmten Aussage: Er ist Herzog und Herr, und kann mit seiner Burg machen, was ihm gefällt. Was jedoch meine Kirche heute hat, das soll er nicht enteignen. Danach verließ er allerdings in der Nacht das Land ${ }^{46}$. Aus der Cosmas' Chronik, in der sich Mstiš mit dem Bischof Šebír zum Festessen in sua curte, que fuit ante ecclesiam setzte, und auch aus den weiteren Worten, die der Chronist dem Mstiš in den Mund legte - quod mea ecclesia habet, versuchen die Historiker das Maximum für die Rekonstruktion der vermögensrechtlichen Verhältnisse

${ }^{42}$ Petr ČECH, Žatec v raném středověku (6. - počátek 13. století), in: Petr Holodňák - Ivana Ebelová (Hgg.), Žatec. Praha 2004, S. 71-78; zur Petrikirche Jindřich TOMAS, Vrcholně středověké město a jeho rozvoj v předhusitské době, in: Ebd., S. 135. Die erste Erwähnung über den Konvent der Minoriten in Žatec/Saaz stammt aus dem Jahre 1314: Urkundenbuch der Stadt Saaz, hg. von Ludwig SCHLESINGER. Prag 1892, S. 7 (Nr. 44), die Einweihung der Konventkirche wird erst 1365 nachgewiesen - ebenda, S. 32 (Nr. 102).

43 ČECH, Žatec v raném středověku, S. 91-95.

44 Die Chronik der Böhmen, S. 106 (II 15-16).

45 Höchstwahrscheinlich am Festtag der heiligen Peter und Paul (den 29. Juni), als Šebír gleichzeitig das 30. Jubileum seiner Bischofskonsekration in Mainz gefeiert hat. Siehe Die Chronik der Böhmen, S. 77 (I 41).

46 Ebd., S. 111 (II 19). 
im böhmischen Přemyslidenstaat im 11. Jahrhundert zu gewinnen. Kein Wunder aber, dass sie dabei zu ganz widersprüchlichen Ergebnissen kommen. Die Aussage der Quelle ist gar nicht eindeutig und wird immer nach vorher angegebener Haltung interpretiert ${ }^{47}$.

Am ehesten gewann Mstiš den Hof von seinen Vorgängern im Dienst des Burgverwalters und mit der Voraussetzung bekommen, dass er darüber nur zur Zeit seiner Wirkung in dieser Funktion verfügen kann. Als er sich entschied, in der Nähe des Hofes die Kirche zu bauen, konnte er es nicht nur aus seinem eigenen Willen machen. Nach Cosmas hat er selbst in seiner Rede zum Herzog Vratislav betont, dass es aus der Gnade des Herzogs Spytihněv geschah. Es ging nicht nur darum, dass die Kirche eigentlich auf dem Herrscherboden erbaut wurde, auch das Verhältnis der neuen Kirche zu der Burgkirche musste klargestellt werden, die wir in Bílina vermuten müssen. Falls Mstišs Kirche auch die mit der Zehnteneinhebung verbundenen Pfarrfunktionen erhielte, würde es zum Nachteil der Burgkirche und nach den allgemein angenommenen Vorstellungen gegen das Interesse des Herrschers geschehen, der als Besitzer so wenigstens teilweise über erworbene Mittel verfügen sollte ${ }^{48}$. Auf der anderen Seite ist es möglich einzuwenden, dass die Vorstellung über die Erträge aus den kirchlichen Zehnten für die weltlichen Kirchenbesitzer meistens erst auf den Quellen aus dem Ende des 12. und aus dem Anfang des 13. Jahrhunderts gegründet ist, bzw. von der Tatsache ausgeht, dass es ungefähr seit der Mitte des 12. Jahrhunderts zu einer großen Gründungswelle dieser Eigenkirchen in Form der Emporkirchen auf dem böhmischen Lande kam ${ }^{49}$.

$\mathrm{Zu}$ einer gewissen Vorsicht bei der Beurteilung jedoch fordert der berühmte Hinweis des Prager Domherrn und Priesters der Marienkirche auf der Prager Burg Zbyhněv aus der Zeit vor dem Jahre 1140 auf ${ }^{50}$. Als er sich entschied, zwei Kanonikerposten in der Kirche in Únětice zu schaffen, spendete er sie aus dem elterlichen Erbe mit dem benachbarten Residenzhof mit seinem wirtschaftlichen Umfeld, den Haustieren (einschließlich des Zuchthengstes und der Stuten, Ochsen, Kühe, Schweine, Gänsen, Hennen und Pfauen), mit nicht geringer Abmessung der Felder, Wiesen und bisher nicht angebautem Land, einer Wassermühle und vor allem mit zahlreichen unfreien Dienstleuten, die den Únětice-Hof im Gang hielten, in der Gesamtzahl 18 Personen. Eher eine Seitenrolle in der Aufzählung des Vermögens, das zum Lebensunterhalt der zwei Kleriker (und in dieser Zeit immer noch auch ihrer Familien) bestimmt wurde, spielte das Einkommen in der jährlichen Höhe von 18 Denaren von zwei proanimatores, von denen einer auch mit seiner Familie noch zu vier Tagen der Leibeigenarbeit verpflichtet wurde ${ }^{51}$. Es fehlt aber

47 Mehr dazu Tomáš VELÍMSKÝ, K problematice pozemkové držby českých velmožů a družiníků v období 11.-12. století, in: Studia medaevalia Bohemica 1 (2009), S. 177-186; DERS., Vzestupy a pády bílinských hradských správců, in: Ivana Boháčová - Petr Sommer (Hgg.), Středověká Evropa v pohybu: k poctě Jana Klápště. Praha 2014, S. 325-363.

48 BOLINA, Př́spěvek k interpretaci Kosmových desátkových údajů, S. 844 f.; besonders dann Josef ŽEMLIČKA, Spor Přemysla Otakara I. s pražským biskupem Ondřejem, in: ČČH 29 (1981), S. 704730, ähnlich DERS., Čechy v době knižecí, S. 240-253; DERS., Počátky Čech královských. Praha 2002, S. 111-131.

49 Als Argument benutzte BOLINA, Ebd., S. 845.

50 Codex diplomaticus et epistolarius Regni Bohemiae. Bd. 1, S. 129-131 (Nr. 124).

51 Aus der neueren Literatur zum Thema: Zdeněk SMETÁNKA, Campus iuxta Suadow et iuxta Colasoy et iuxta Hriunatecz, (K otázce systému obdělávání polí v raném středověku), in: Studia mediaevalia Pragensia 2 (1991), S. 105-115; DERS., Legenda o Ostojovi. Praha 1992 (zweite erweiterte Ausgabe Praha 2004); Tomáš PETRÁČEK, Fenomén darovaných lidí v Čechách. Praha 2003, vor allem S. 96-98; KLÁPŠTĚ, Proměna českých zemí ve středověku, S. 56 f. Zuletzt Tomáš VELÍMSKÝ, Paní Bohatěj a její 
irgendeine Erwähnung des kirchlichen Zehnten, der doch theoretisch die Absicherung der Kleriker, die Wartung und den Betrieb Zbyhněvs Únětice-Kirche decken könnte. Wir können nur vermuten, warum Zbyhněv die Lösung wählen musste, mit der er auf sein Vermögen griff, das er von seinen Eltern vererbte. Wir sollten wohl zustehen, dass die Gründung der Eigenkirchen nicht nur ökonomisch motiviert sein musste. Eine große Rolle konnte auch das Prestige spielen, dass der Gründer gewann, und den Fundatoren fehlte bestimmt nicht an der religiösen Motivation. Sie glaubten ohne Zweifel daran, dass sie durch die Kirchengründung ihre Sünden und Schulden abbüßen und so die Hoffnung auf ewiges Heil für sich selbst und ihre Verwandte verstärken können. Zbyhněv äußerte auch in seinem Testament den Wunsch, in der Kirche beerdigt zu sein. Man kann nur bedauern, dass die ursprüngliche mittelalterliche Kirche in Únětice nicht erhalten blieb und dass keine archäologische Forschung hier durchgeführt wurde. Wir können also nur vermuten, wie sie aussah. Für diese Zeit kann man sich am ehesten entweder einen einfachen longitudinalen einschiffigen Bau mit der halbrundbeendeten Apside oder eine Rotunde vorstellen. Dieses Aussehen hatte sowohl Osels Pankratiuskirche in Krušina, als auch die von Únětice nicht weit entfernte Rotunde in Přední Kopanina, die sogar schon mit dem westlichen Turm ausgestattet wurde ${ }^{52}$.

Falls wir versuchen, direkte Belege über den privaten Grundbesitz der Angehörigen der Gefolgseliten zusammenzufassen, die eigentlich immer mit den Donationen den Kircheninstitutionen zusammenhängen, ist es zu konstatieren, dass sie wirklich selten sind. Zurzeit wird die Diskussion darüber geführt, bis zu welchem Maße - neben den Herzogen Oldřich und Břetislav I. - sich selbst der Gründer und der erste Abt Prokop an der Fundation des Klosters in Sázava beteiligen konnte. Während P. Sommer geht vor allem von der Argumentation von J. Žemlička aus und Prokop's Teilnahme ablehnt ${ }^{53}$, rechnen die anderen Forscher mit ihr ${ }^{54}$. Das Problem liegt darin, dass die Prokopslegenden selbst keine eindeutige Antwort auf diese Frage geben können und die Schlussfolgerungen der einzelnen Autoren sind wieder davon beeinflusst, von welcher Stellung bezüglich des möglichen Grundbesitzes der frühen Eliten sie apriorisch ausgehen. Prokops Vermögensteilnahme an der Gründung des Klosters ist jedoch nicht ganz auszuschließen, wenn auch die Fürsten Oldřich und sein Sohn Břetislav dabei ohne Zweifel eine entscheidende Rolle spielten.

In dieser Hinsicht kann man vielleicht die Gründung des Sázava-Klosters mit den Angaben über die Gründung des Klosters in Opatovice vergleichen. Die Urkunde, die sich zum Jahre 1073 meldet, ist ein Falsum aus der Zeit nach der Mitte des 12. Jahrhunderts, das aber von den glaubwürdigen Angaben ausgeht, die wahrscheinlich in einer älteren

blízcí, in: Martin Nodl - Martin Wihoda (Hgg.), Šlechta, moc a reprezentace ve středověku. Praha 2007, S. 53-62.

52 Zdeněk DRAGOUN, Praha 885-1310: kapitoly o románské a raně gotické architektuře. Praha 2002, S. $210 \mathrm{f}$.

53 Petr SOMMER, Svatý Prokop: $z$ počátků českého státu a církve. Praha 2007, S. 110-122; Josef ŽEMLIČKA, Hmotné zabezpečení nejstarších benediktinských klášterů v Čechách, in: Petr Sommer (Hg.), Svatý Prokop, Čechy a Evropa. Praha 2006, S. 265-276.

54 Marie BLÂHOVÂ - Jan FROLÍK - Nada PROFANTOVÁ, Velké dějiny zemí Koruny české. Bd. 1. Praha - Litomyšl 1999, S. 370; Martin WIHODA, Sázavský klášter v ideových souřadnicích českých dějin 11. věku, in: Sommer (Hg.), Svatý Prokop, Čechy a Evropa, S. 237-250; gespitzt polemisch Libor JAN, Skrytý půvab „středoevropského modelu“, in: ČČH 105 (2007), S. 886 f. 
schriftlichen Quelle notiert wurden ${ }^{55}$. Es stimmt aber nicht das Jahr der Gründung der Kirche überein, zu der offensichtlich erst in der Zeit kam, als Vratislav II. schon König (so wird er in der Urkunde tituliert) war, also nach dem Jahre 1085, am wahrscheinlichsten in den Jahren 1086-108756. Der Herrscher gründet das Kloster mit der Lorenzkirche, dessen Vorgänger cella des Břevnov-Klosters war, die vom Vordermann (primas) Mikulec errichtet wurde. Vielleicht könnte man das Datum 1073 gerade auf diese ursprüngliche cella beziehen. Zum Abt des Klosters ernannte Vratislav seinen Kaplan Andreas. Danach zählt man Herrschers Schenkung mit den Dörfern, Feldern, unfreien Dienstboten, aber auch mit den Benefizien in Form der Zehnten aus den Märkten und anderen Einkommen aus den mährischen Burgen (civitates). Das Kloster erhielt auch das Vermögen von weiteren Personen: der schon erwähnte Mikulec schenkte das Land auf einen Acker in Vraclav, also irgendwo im nächsten Hinterland der Přemyslidenburg, das Land auf einen Acker im Dorf Plačice erhielt das Kloster vom Propst Tezlin (Tiselina) aus der Burg Hradec (Königgrätz), der Abt Bolerad (war er Abt von Opatovice vor Andreas oder es handelte sich um den Abt aus einem anderen existierenden Benediktinerkloster in den böhmischen Ländern?) schenkte das Land Liběšice (territorial nicht spezifizierter Raum einer neuen Siedlung?), der Hofkaplan Geco (Jek?) widmete das Dorf Platěnice und der Vordermann Všebor widmete das Dorf Lodín. Der letzte erwähnte Mann war wahrscheinlich der Angehörige der bedeutenden großmächtigen Familie der Hrabišicer. Alle erwähnten Lokalitäten, außer Vraclav, befinden sich in der Nähe des Klosters. Das bedeutet, dass sich schon ein wirklich nicht vernachlässigbares privates Grundvermögen im letzten Viertel des 12. Jahrhunderts auf einem relativ kleinen Gebiet konzentrierte.

Seit dem Ende des 11. Jahrhunderts erscheinen in den Quellen auch Belege über die Fundationen der Kirchen, deren Gründer die Angehörigen der frühen Nobilität waren. In zwei Verzeichnissen der Schriftstücke des Prager Domkapitels aus der nachhussitischen Zeit blieb Kenntnis von einer Urkunde erhalten, in der Zbudek, der Domherr der Bischofskirche und Propst des Kapitelstiftes in Stará Boleslav/Altbunzlau, im Jahre 1098 der Prager Kirche sein geerbtes Grundvermögen schenkte (bona patrimonialia, bzw. patrimonium). Im älteren Verzeichnis der Schriftstücke aus dem Jahre 1454 befindet sich nur eine Erwähnung über das geschenkte Vermögen, in dem jüngeren (ohne genauere Datierung) wurde der Inhalt der Urkunde abgeschrieben ${ }^{57}$. Dank dieser Abschrift sind wir informiert, dass der Domherr die Kirche mit dem Patrozinium der Jungfrau Maria und St. Georgs in Boleslav gründete und gleichzeitig der Prager Kirche aus seinem erblichen Vermögen ein Gut (predium) in Letňany schenkte und zwar mit Ausnahme des Zehnten aus dem Erlös, der für die Kirchen in Boleslav, also für die Stiftkirche des heiligen Wenzels und für seine neugegründete Kirche, bestimmt wurde. Dem Prager Domkapitel schenkte er auch das Patrimonium im Dorf Slatina, genauso wie animatores und alle Erträge von den Wiesen und Weiden (omnem fructum cum prato) aus dem

55 Rostislav NOVÝ, Diplomatické poznámky k donačním listinám českých klášterů a kapitul do konce 12. století, in: Studia mediaevalia Pragensia 2 (1991), S. 129 f.

56 Codex diplomaticus et epistolarius Regni Bohemiae. Bd. 1, S. 368-371 (Nr. 386). Der mit der Geschichte seines Klosters bestimmt gut vertraute Abt Neplach, erwähnt in seiner Chronik die Gründung zum Jahr 1088 schon als realisiert: Kronika Neplachova, hg. von Josef EMLER, Fontes rerum bohemicarum. Bd. 3. Praha 1882, S. 468.

57 Ausführliche und überzeugende Quellenanalyse führte Jiří PRAŽÁK, Nejstarší listina pražského kostela, in: Sborník archivních prací 10/1 (1960), S. 215-229, durch. 
Dorf Brzescan (Břeštany?). Nach der Beschreibung wurde die Urkunde mit dem Siegel des Herzogs Břetislav II. bekräftigt, auf dessen Rückseite sich das Contrasigillum des Bischofs Heřman befand. Weil er im Jahre 1098 noch nicht Bischof war, sondern Zbudeks Vorgänger in der Funktion des Propstes im Boleslaver Kapitelstift, ist es klar, dass die Spende nachträglich, erst im Laufe der Jahre 1099-1100 aufgeschrieben wurde, während sich das in der Urkunde genannte Jahr 1098 zum realen Datum der Donation bezieht. Die Lage der Marien- und Georgskirche in Stará Boleslav wird mit der barocken MariaHimmelfahrt-Wallfahrtskirche auf dem Marktplatz identifiziert, man kann aber nicht ausschließen, dass es sich um eine untergegangene romanische Kirche handeln könnte, deren Grundriss durch die archäologische Forschung der Burgakropol entdeckt wurde ${ }^{58}$.

Zbudek ist also nach Mstiš der erste bekannte - und in diesem Falle unzweifelhafte Kirchengründer, der aus der Umgebung der böhmischen Gefolgseliten stammte. Er selbst war aber nie der Kirchenbesitzer. Als Domherr und später auch Propst des Altbunzlauer Kapitelstiftes überwies er die Kirchenrechte auf das Stift oder auf seine späteren Nachfolger im Amt des Propstes, sodass die Kirche im Besitz dieser Kircheninstitution, bzw. ihres Vorgesetzten war.

Nach Zbudek vermehren sich im Laufe der ersten Hälfte des 12. Jahrhunderts die Berichte über die Kirchengründer. Unter diesen Quellen ist auf der ersten Stelle die Urkunde zu nennen, mit der König Přemysl Otakar I. im Jahre 1205 die Vermögen des Klosters in Ostrov bestätigen sollte. Es geht um den zweitältesten männlichen Benediktinerkonvent in Böhmen. Er wurde auf Wunsch des Herzogs Boleslav II. nicht lange nach seinem Tod (also im Laufe der Jahre 999-1000) von seinem Sohn Boleslav III. auf einer Moldauinsel, nicht weit vom Zusammenfluss mit der Sázava, gegründet. Die Urkunde bezeichnete der Herausgeber des böhmischen diplomatischen Kodexes Gustav Friedrich als Falsum, weil sie wahrscheinlich in dem Jahr, über dem informiert, nicht geschrieben wurde; er zweifelte aber nicht daran, dass sie glaubwürdige Angaben enthält, die aus der Reihe der älteren, im Kloster bewahrenden Aufzeichnungen ausgehen. Zu derselben Ansicht gelangten im Laufe der Zeit auch weitere tschechische Historiker, die sich mit der Urkunde beschäftigten ${ }^{59}$. Sie kamen zum Schluss, dass zur Ausfertigung des Falsums zwar erst am Anfang des 14. Jahrhunderts kam, sein Inhalt ging jedoch von einem Verzeichnis des Klostervermögens aus, das nicht lange nach 1150 erstellt wurde.

Die Urkunde führt zuerst die Donationen und Privilegien an, mit denen der König Přemysl Otakar I. das Kloster bereicherte. Danach folgt die Zusammenfassung der Spenden der einzelnen Přemysliden-Herrscher, deren Reihe mit dem Gründer Boleslav III. beginnt und mit Svatopluk endet (1107-1109). Erst danach folgt der Abschnitt, der mit den Worten ...Hec sunt beneficia primatum eingeführt wird. Er enthält die Aufzählung des Vermögens, das Großmächtige, Vorderleute und andere Gefolgskämpfer der böhmischen Herzöge dem Kloster widmeten. Nicht alle Schenkungen stammen aus derselben Zeit, einige konnten später eingeschrieben werden, wie es auch aus den Formulierungen

58 Ivana BOHÁČOVÁ - Jaroslav ŠPAČEK, Třetí raně středověký kostel na akropoli hradiště v Staré Boleslavi, in: Archeologické rozhledy 46 (1994), S. 607-617; Ivana Boháčová (Hg.), Stará Boleslav: přemyslovský hrad v raném středověku. Praha 2003.

59 Codex diplomaticus et epistolarius Regni Bohemiae. Bd. 2, S. 379-383 (Nr. 359). Zu der Urkunde Václav HRUBÝ, Tři studie $k$ české diplomatice. Brno 1936, S. 138-144; Jindřich ŠEBÁNEK - Saša DUŠKOVÁ, Listina v českém státě doby Václava I., in: Rozpravy ČSAV 73/10 (1963). Bild 28, Bemerkung 1; NOVÝ, Diplomatické poznámky k donačním listinám, S. 129 f. 
hervorgeht. Unter den Spendern wird z. B. Pavel eingeführt, einst ein Mann des großen Namens, der Vorfahre von Klimata aus Všenor (eciam magni nominis homo, attavus Climate de Wsenor). Der Name von Klimata ist mit Prädikat angegeben und das bedeutet, dass sich dieser Vordermann nach einem Dorf bezeichnete, das er besaß. Die Prädikate erscheinen in den Quellen aus dem böhmischen Milieu gerade um die Mitte des 12. Jahrhunderts ${ }^{60}$. Nach der Donation des Vordermannes Chotimír, des Sohnes von Hýlek (filius Hilconis) folgen in ähnlicher Weise die Vermächtnisse der Gebrüder Kř́íz und Přistan, Chotimirs Nachkommen (de stirpe predicti Chotyemyri). Einige der Spender, die im Ostrover Falsum erwähnt sind, kann man auch aufgrund anderer Erwähnungen in den Quellen identifizieren, die die Tatsache bezeugen, dass diese Leute schon im ersten Viertel des 12. Jahrhunderts zu den Eliten der böhmischen Gesellschaft gehörten.

Über Nožislav, Lubomírs Sohn, der dem Kloster Ostrov vier Gehöfte (Acker) mit einem Obstgarten und Wald im Dorf Dobrríč schenkte, liest man wiederholt in der Chronik von Cosmas. In der letzten Erwähnung zum Jahre 1110 gibt der Chronist an, dass Nožislav zusammen mit seinem Bruder Držikraj in der Schlacht fiel, die der Herzog Vladislav I. mit der Truppe seines Bruders Soběslav und des polnischen Herzogs Bolesław III. Schiefmund lieferte ${ }^{61}$. Zum März des Jahres 1123 verzeichnete Cosmas, dass sich der Vordermann Dlúhomil, der dem Kloster Ostrov das Dorf Mezouň mit drei Wäldern schenkte, zusammen mit dem Bischof Jindřich Zdík (Heinrich II. Zdik) und den anderen auf die Pilgerfahrt nach Jerusalem aufmachte und auf der Rückfahrt am 8. Juli starb. Die Nachricht von seinem Tod brachten die anderen Teilnehmer der Pilgerfahrt nach Böhmen, denen es vergönnt war, im November heimzukehren ${ }^{62}$.

Der ausgezeichnete Vordermann Mladota (egregius primas), der dem Kloster Ostrov sechs Acker in den Dörfern Vršovice und Kolovraty schenkte, wurde auch unter den Zeugen aus der Zeit des Herzogs Soběslav (1125-1140) in der sog. Gründungsurkunde für das Kloster in Kladruby erwähnt. Die Urkunde ist zwar wieder ein Falsum aus der Zeit nach dem Jahre 1186, vielleicht aus dem Anfang des 13. Jahrhunderts, das jedoch von den realen Fakten ausgeht ${ }^{63}$. Mladota wird vor allem im Jahre 1137 in der Chronik des sog. Kanoniker von Vyšehrad, eines der Fortsetzer des Chronisten Cosmas, erwähnt und zwar in der Legende über die Genesung einer Frau aus Běstvina in der Čáslaver Provinz. Sie wurde wundersam zur Gotthardi-Basilika in Slapy hinübergetragen, die früher derselbe adelige und mächtige (nobilis et potens) Mladota bauen ließ ${ }^{64}$. Mladota gründete also die Kirche, die sogar das Aussehen der Basilika hatte und vertraute sie in den Schutz des Heiligen an, der gerade zu dieser Zeit in Böhmen beliebt war ${ }^{65}$. Ob die Kirche wirklich

${ }^{60}$ Der älteste Beweis über Prädikat findet man in zwei Urkunden aus den Jahren 1146-1148, in den unter den Zeugen figuriert Marquart de Dubraua - Codex diplomaticus et epistolarius Regni Bohemiae. Bd. 1, S. 161-165 (Nr. 157 und 158).

${ }^{61}$ Die Chronik der Böhmen, S. 209 (III 36).

62 Ebd., S. 223 (III 51).

${ }^{63}$ Codex diplomaticus et epistolarius Regni Bohemiae. Bd. 1, S. 401 (Nr. 390). Siehe NOVÝ, Diplomatické poznámky k donačním listinám, S. 137 f.

${ }^{64}$ Letopis Kanovníka vyšehradského, in: Fontes rerum bohemicarum. Bd. 1, hg. von Josef EMLER. Praha 1874, S. 226.

65 Nach der Kanonisation im Jahre 1131. Siehe Josef ŽEMLIČKA, Úcta svatého Gotharda v přemyslovských Čechách, in: Petr Kubín (Hg.), Světci a jejich kult ve středověku. Praha 2006, S. 345-349. 
in Slapy ${ }^{66}$ oder in Slaný ${ }^{67}$ stand, können wir momentan beiseite liegen: In Slapy blieb die ursprüngliche Kirche nicht erhalten, die städtische Gotthardi-Pfarrkirche in Slaný enthält Relikte der ursprünglichen romanischen Kirche, vielleicht der Basilika aus dem zweiten Viertel des 12. Jahrhunderts ${ }^{68}$.

Derselbe Chronist bemerkt noch eine interessante Sache, die leider nicht mehr konkretisiert wird: Als der Prager Bischof Jan/Johann aus Mainz im Frühjahr 1135 nach Böhmen zurückkehrte, wo er vom Kaiser Lothar III. die Abzeichen seiner Bischofswürde erhielt und vom Erzbischof dann eingeweiht wurde, sollte er noch vor der Ankunft nach Prag eine Kirche weihen, die ein unbenannter böhmischer Vordermann gegründet hatte ${ }^{69}$.

Kehren wir aber zu der Ostrover Urkunde zurück. Für uns sind drei Erwähnungen am wichtigsten. Die erste gibt an, dass Zbraslav, quoque magne memorie vir, dem Kloster Benefizium in der Form einer Kapelle des heiligen Vojtěch/Adalbert und ein Land für fünf Gehöfte (Acker/aratra) im Dorf Tutleky (auch Havraň genannt) schenkte ${ }^{70}$. Die Lokalisierung des Ortes ist schwer, Antonín Profous neigte zu Tuklaty, einem untergegangenen Dorfesteil von Třebusice in der Gegend von Slaný ${ }^{71}$. Das ist eine Lösung, die der Tatsache entsprechen würde, dass das Kloster Ostrov gerade in diesem Gebiet Böhmens mehrere Besitzungen hatte ${ }^{72}$. Diese Lösung beachtet aber nicht den zweiten Namen der Siedlung - Havraň. Deshalb scheint eine andere Lösung wahrscheinlicher zu sein, die die Verbindung mit Havraň in der Nähe von Nymburk voraussetzt, eventuell mit dem untergegangenen Dorf Vykleky irgendwo in der Umgebung. Die beiden Lokalitäten werden im Testament des königlichen Schenkes Zbraslav, des Sohns von Vchyna, aus dem Jahre 1238 erwähnt ${ }^{73}$. Zbraslav kaufte Vykleky für Geld seiner Ehefrau Domaslava und deshalb erkannte er jetzt ihr das Dorf an, genauso wie einen Teil von Havraň, den er für fünf Pfund Silber kaufte ${ }^{74}$. Diesen Zbraslav betrifft eine Reihe von Quellenerwähnungen, die uns ermöglichen, die Endphase seiner Karriere wenigstens relativ gut zu rekonstruie-

${ }^{66}$ Slapy wurde später ein Bestandteil des landesherrlichen Vermögens, Václav II. schenkte es dem neugegründeten Zisterzienskonvent Aula Regia in Zbraslav. Das bestätigt die Urkunde zum Jahr 1304 Regesta diplomatica nec non epistolaria Bohemiae et Moraviae. Bd. 2, hg. von Josef EMLER, S. 866 (Nr. 2004). Die Existenz der Pfarrkirche ist zum Jahr 1352 bewiesen: Registra decimarum papalium čili registra desátků papeženských $z$ dioecezí Pražské, hg. von Václav Vladivoj TOMEK. Praha 1873, S. 41; die erhaltene Barockkirche ist aber seit 1644 mit dem Peter und Paul-Patrozinium erwähnt.

67 Zdeněk BOHÁČ befasste sich gründlich mit den Belegen für die mittelalterlichen Kirchen in Slapy und Slaný, Topografický slovník k církevním dějinám předhusitských Čech. Pražský archidiakonát. Praha 2001, S. 75 und 169. Zu Slaný auch Josef ŽEMLIČKA, Slaný - opožděné založení jednoho královského města, in: Zdeněk Kuchyňka (Hg.), Slaný. České město ve středověku: sborník př́ispěvků z kolokvia k 700. výročí královského města Slaného. Kladno/Slaný 1997, S. 10, Fußnote 16.

68 Věra NAŇKOVÁ, Slaný, in: Emanuel Poche (Hg.), Umělecké památky Čech. Bd. 3. Praha 1980, S. 336 f.

${ }^{69}$ Letopis kanovníka vyšehradského, S. 222.

70 Codex diplomaticus et epistolarius Regni Bohemiae. Bd. 2, S. 382 (Nr. 359).

71 Antonín Profous - Jan Svoboda (Hgg.), Místní jména v Čechách. Jejich vznik, pưvodní význam a zmèny. Bd. 4. Praha 1957, S. 396.

72 Siehe die Konfirmation des Vermögens des Klosters in Ostrov vom Papst Kliment V. aus dem Jahre 1310 - Regesta diplomatica nec non epistolaria Bohemiae et Moraviae. Bd. 2, S. 971-972 (Nr. 2243).

73 Codex diplomaticus et epistolarius Regni Bohemiae. Bd. 3. Teil 1, hg. von Gustav FRIEDRICH. Praha 1942, S. 225-227 (Nr. 181).

${ }^{74}$ Zu Zbraslav Josef ŽEMLIČKA, Královský číšník Zbraslav a jeho dědictví (Vznik a rozklad jednoho feudálního dominia z první poloviny 13. století), in: Historická geografie 21 (1983), S. 117-132. Zusammenfassend DERS., Počátky Čech královských 1198-1253: promèna státu a společnosti. Praha 2002, S. $407 \mathrm{ff}$. 
ren. Im Jahre 1228 ist er in der Zeugenreihe der Urkunde des jüngeren Königs Wenzel I. für den Zisterzienserkonvent in Oslavany zu finden, in der er als Königs Unterschenke (subpincerna $)^{75}$ bezeichnet wird und in dieser Funktion begleitete er Václav I. in den folgenden Jahren ${ }^{76}$. Er bekleidete dieses Amt noch im Februar $1238^{77}$. Um zwei Monate später, im April 1238, machte er in Vykleky sein Testament, in dem er sich schon als königlicher Schenke bezeichnet (pincerna) ${ }^{78}$. Es bleibt ein bisschen rätselhaft, warum die Inschrift seines Siegels (+SIGILLUM.SBRASLAV.DAPIFER.REGIS), mit dem er die Urkunde besiegelte, ihn als Truchse $\beta /$ Tafelmeister bezeichnet ${ }^{79}$. Die Beförderung genieß er nur kurz, schon am 5. Mai 1238 begleitete Herr Bavor von Strakonice den König als Schenke und Zbraslavs Ehefrau Domaslava wird schon im Oktober 1241 als Witwe genannt ${ }^{80}$.

Es entsteht aber eine Grundfrage. Falls Zbraslav in der Ostrover Urkunde figuriert, der aus den Belegen aus den Jahren 1228-1238 bekannt ist, dann würde diese Urkunde gegen die oben genannten Voraussetzungen von jüngeren Aufzeichnungen kontaminiert, die weit hinter die obere Grenze der Mitte des 12. Jahrhunderts greifen. Wir können dies nicht ausschließen, obwohl es andererseits verlockend wäre zuzugeben, dass der Schenke Zbraslav ein Nachkomme von Zbraslav aus der Ostrover Urkunde sein könnte. Zbraslavs Testament aus dem Jahre 1238 ermöglicht eine bestimmte Einsicht in seine Verwandtschaftsverhältnisse, außer dem Vater Vchyna wurden auch seine Brüder Ojír/Hoger und Řivin/Rivin genannt. Das sind Eigennamen, die im böhmischen Milieu nicht zu gewöhnlich waren. Wenn wir zulassen würden, dass - ähnlich wie in den anderen Fällen - sich die Namen in der Familie in mehreren Generationen wiederholten, dann wäre es möglich, bestimmte Zusammenhänge zu finden. Im Jahre 1228 figurierte unter den Höflingen des Königs Přemysl Otakar I. der Truchsess Ojíŕ ${ }^{81}$, der Zbraslavs Bruder sein könnte. Ist es ein völliger Zufall, dass ein Truchsess Řivin ${ }^{82}$ um zwei Generationen früher in der Begleitung des Herzogs Soběslav II. zu finden ist? Als der Chronist Cosmas im Jahre 1113 die dramatische Flucht des Fürsten Soběslav (später des Herzogs Soběslav I.) aus dem sächsischen Gefängnis vermerkte, erwähnte er, dass auch der Gefolgsmann Konrad, der Sohn von Řivin, zusammen mit dem Fürsten entfloh ${ }^{83}$. Und wieder ein gewisser Zusammenhang: in den Jahren 1146-1148 war ein Mann namens Konrad der Truchsess des Herzogs Vladislav II. ${ }^{84}$. Könnte also die Bezeichnung dapifer aus dem Zbraslavs Siegel aus dem Jahre 1238 seine Sehnsucht erklären, sich mit den

75 Codex diplomaticus et epistolarius Regni Bohemiae. Bd. 2, S. 324-327 (Nr. 323).

76 Vgl. Codex diplomaticus et epistolarius Regni Bohemiae. Bd. 3. Teil 4, hg. von Jan BYSTřICKÝ. Olomouc 2002. Register, S. 588.

77 Codex diplomaticus et epistolarius Regni Bohemiae. Bd. 3/1, S. 217 (Nr. 175).

78 Ebd., S. 225-227 (Nr. 181).

79 Das Abbild des Siegels siehe Codex diplomaticus et epistolarius Regni Bohemiae. Bd. 3. Teil 3, hg. von Gustav FRIEDRICH - Zdeněk KRISTEN - Jan BISTŘICKÝ. Olomouc 2000. Appendix II. Sigilla 10. In der umgezeichneten Form August SEDLÁČEK, Atlasy erbů a pečetí české a moravské šlechty, hg. von Vladimír Růžek. Bd. 5. Praha 2003, S. 200.

80 Codex diplomaticus et epistolarius Regni Bohemiae. Bd. 4. Teil 1, hg. von Zbyněk SVITÁK - Helena KRMÍČKOVÁ - Jarmila KREJČÍKOVÁ. Praha 2006, S. 67-69 (Nr. 8).

81 Codex diplomaticus et epistolarius Regni Bohemiae. Bd. 2, S. 323 (Nr. 321).

82 Die Urkunde aus den Jahren 1175-1178: Codex diplomaticus et epistolarius Regni Bohemiae. Bd. 2, S. 251 (Nr. 285).

83 Die Chronik der Böhmen, S. 212 (III 39).

84 Codex diplomaticus et epistolarius Regni Bohemiae. Bd. 1, S. 163 und 165 (Nr. 157-158). 
Ahnen und Verwandten zu vergleichen? Zbraslav aus der Zeit vor der Mitte des 12. Jahrhunderts, den wir suchen, könnte unter den Zeugen aus der Reihe der Gefolgsleute in dem schon erwähnten Paar der Urkunden aus den Jahren 1146-1148 figurieren ${ }^{85}$. Der Vordermann (primas) Zbraslav tritt auch in der Urkunde des Königs Vladislav aus dem Jahre 1160 auf $^{86}$.

Nicht einmal die zweite Erwähnung aus der Ostrover Urkunde, mit der wir uns beschäftigen werden, kann unsere Unsicherheit zerstreuen. Unter den Donatoren ist ein gewisser miles Bolečej angegeben, der die Kapelle des heiligen Vojtěchs/Adalberts in Hrusice, ein Land für drei Gehöfte (aratra), einen Wald und noch ein Land für zwei Gehöfte in Úžice dem Kloster schenkte ${ }^{87}$. Die Donation konnte sich in der Zeit vor der Mitte des 12. Jahrhunderts ereignen. Weil Bolečej als miles bezeichnet ist, würde es in diesem Zeitkontext einen Gefolgsmann und Kämpfer bedeuten, wie wir es schon am Beispiel des von Cosmas erwähnten Konrad, des Sohns von Řivin sahen. Im Gegensatz zu den bisher genannten Kirchen, deren Beschenkung in den schriftlichen Quellen erscheint, blieb die romanische Kirche in Hrusice erhalten. Sie ist heute dem heiligen Wenzel eingeweiht, der - wahrscheinlich mit dem heiligen Vojtěch/Adalbert - in der einfachen Reliefdarstellung am Tympanon des Portals an der nördlichen Seite des Schiffes zu sehen ist. Die Kirche ist ein einschiffiger Bau, ursprünglich flachdeckig mit einer halbzylindrischen Apside und einem westlichen Turm, dessen Raum sich im Stock mit dem Bogen ins Schiff öffnete. Der Wandabsatz im westlichen Schiffteil zeugt davon, dass hier vermutlich ursprünglich eine seichte Empore war. Das Kapitell, das sekundär in der Friedhofsmauer benutzt wurde, gehörte vermutlich zur Säule, die die Empore stützte. Die Ausschmückung dieses Kapitels korrespondiert mit der Ausschmückung des Absatzportals, das aber die kunsthistorische Literatur erst am Anfang des 13. Jahrhunderts datiert ${ }^{88}$, also in die Zeit, als - falls zu Bolečejs Donation dem Ostrover Kloster vor der Mitte des 12. Jahrhunderts käme - die Kirche schon einige Jahrzehnte im Besitz des Ostrover Klosters sein sollte. Der Um- oder Neubau der Kirche aus der Initiative ihres Kirchenbesitzers wäre sicher möglich, warum würde sie aber die Form der Emporkirche bekommen? Es bietet sich allerdings noch eine Lösung an: Das Dorf Hrusice blieb offensichtlich weiterhin in den Händen der weltlichen Besitzer ${ }^{89}$ und wie man für spätere Zeit nachweisen kann, behielt sich das Ostrover Kloster keine Rechte zur Kirche bei ${ }^{90}$. Dann würde die Realisierung der Eigenkirche mit der Empore nicht einmal am Anfang des 13. Jahrhunderts ihren Sinn verlieren.

85 Ebd.

${ }^{86}$ Codex diplomaticus et epistolarius Regni Bohemiae. Bd. 1, S. 197-199 (Nr. 210). Dazu mehr Tomáš VELÍMSKY, O královském podčeším, který toužil stát se stolníkem, in: Eva Doležalová - Petr Sommer (Hgg.), Středověký kaleidoskop pro muže s hůlkou: věnováno Františku Šmahelovi k životnímu jubileu. Praha 2014, S. 665-677.

87 Codex diplomaticus et epistolarius Regni Bohemiae. Bd. 2, S. 383 (Nr. 359).

88 Anežka MERHAUTOVÁ, Raně středověká architektura v Čechách. Praha 1971, S. 127 f.

89 Zum Jahre 1325 wurde Slavek von Hrusice als Bürge (fideiussor) beim Landesgericht in einem Vermögensstreit erwähnt - Reliquiae Tabularum terae regni Bohemiae. Bd. 1, hg. von Josef EMLER. Praha 1899 , S. 67.

90 Zum Jahre 1359 Ondřej von Dubá - Libri Confirmationum. Bd. 1. Teil 1, hg. von František Antonín TINGL. Praha 1867, S. 88 und S. 110; zum Jahr 1383 wieder Ondřej von Dubá - Libri Confirmationum. Bd. 3. Teil 4, hg. von Josef EMLER. Praha 1879, S. 158. 
Die Aufschreibungen über die Elitendonationen wechselt in der Ostrover Urkunde eine Passage, die die Geschenke des Herzogs Vladislav aufzählt, des Enkelkindes Vratislavs, also Vladislav II. aus der Zeit vor Erlangung des Königstitels (bis zum Jahr 1158). Danach ist die Donation verzeichnet, die miles Osel (Asinus), der Sohn von Hoza tat. Fürs Heil seiner Seele und der Seele seiner Eltern vermachte er dem Kloster die Kirche in Krušina mit dem Land für ein Gehöft (aratra). Weiter schenkte er ihm auch das Gut (predium) in Přistoupim und weiter ein Land genügend für ein Gehöft in Pocatycyh, einem Dorf, das wir nicht identifizieren können, vielleicht weil es unterging.

Mit der Kirche konnte auch die Donation von Přibyslava verbunden werden, der Witwe des Adligeres Hroznata, über die der als Mönch von Sázava bezeichnete Chronist eine Nachricht hinterließ ${ }^{91}$. Nach dem Tod ihres Vaters und ihres einzigen Sohnes Šebír entschied sie sich, sich mit dem Bischof Menhart auf die Pilgerfahrt nach Jerusalem aufzumachen ${ }^{92}$. Nach der Rückkehr nach Böhmen, als sie spürte, dass sich ihr Tod nähert, erklärte sie in der Anwesenheit ihrer Verwandten und anderer Vorderleuten ihr Vermächtnis zugunsten des Sázaver Klosters; vor allem schenkte sie das Dorf Hostivař mit einem Wald, Feldern, Wiesen und allem Zubehör, genauso wie ihre unfreie Dienstleute und dazu noch das Dorf Bosákovice. Hostivař wird wieder 1185 im Text der Urkunde erwähnt, die im Kapitelstift Vyšehrad irgendwann im 14. Jahrhundert abgeschrieben wurde. Die Urkunde bestätigte dem Kapitel die Donation im Dorf Záběhlice, wobei unter den Zeugen der vom Herzog Bedřich/Friedrich konfirmierten Urkunde, auch die freien Landwirte - Erben (heredes) aus den umliegenden Dörfern Hostivař, Chodov, Roztyly und Strašnice waren ${ }^{93}$. In Hostivař blieb eine einschiffige romanische Johanniskirche erhalten, die die ältere kunsthistorische Literatur schon mit dem Ehepaar Hroznata und Přibyslava verband und sogar zum Ende des 11. oder am Anfang des 12. Jahrhunderts datierte $^{94}$. Zu dieser Datierung äußerte sich Z. Dragoun mit Recht skeptisch, obwohl er nicht ausschloss, dass die Kirchenapside aus der älteren Kirche stammen konnte, die hypothetisch wieder eine Rotunde sein könnte ${ }^{95}$.

Um die Mitte des 12. Jahrhunderts kommt es in der Entwicklung des Vermögensbesitzes der Gesellschaftseliten zur markanten Dynamisierung. Ihr erstes Merkmal ist die Erscheinung der Prädikate, die die Namen dieser Personen in den Zeugenreihen der Urkunden zu begleiten beginnen. Nach Markvart von Dubrava, dessen Name in zwei Urkunden des Herzogs Vladislav II. aus den Jahren 1146-1148 erschien ${ }^{96}$, kommen allmählich weitere Beweise hinzu ${ }^{97}$. Das zweite Phänomen ist die schnell zunehmende Anzahl der romanischen, mit der Westempore ausgestatteten Eigenkirchen. Damit öffnet sich ein neues Kapitel der Geschichte der mittelalterlichen Nobilität Böhmens, das mit dem

\footnotetext{
91 Mnich sázavský, in: Fontes rerum bohemicarum. Bd. 2, hg. von Josef EMLER, S. 258.

92 Die Erwähnung von der Erreichung Jerusalems zum Jahre 1130 in Zusammenhang mit dem Bischof Menhart und Přibyslava befindet sich auch in Letopisy pražské, hg. von Josef EMLER, Fontes rerum bohemicarum. Bd. 2, S. 378.

93 Codex diplomaticus et epistolarius Regni Bohemiae. Bd. 1, S. 277-279 (Nr. 308).

94 So auch MERHAUTOVÁ, Raně středověká architektura v Čechách, S. $248 \mathrm{f}$.

95 Zdeněk DRAGOUN, K stavebnímu vývoji kostela Stětí sv. Jana Křtitele v Hostivaři, in: Staletá Praha 20 (1990), S. 100-115; DERS., Praha 885-1310, S. 226 f.

96 Codex diplomaticus et epistolarius Regni Bohemiae. Bd. 1, S. 163 (Nr. 157) und S. 165 (Nr. 158).

97 Vgl. KLÂPŠTĚ, Proména českých zemí ve středověku, S. 88 f. und Fußnote 193 auf Seite 434.
} 
Aufschwung des Vermögensbesitzes der bisherigen Großmächtigen und Vordermänner verbunden ist. Das ist jedoch schon ein Thema für einen anderen Beitrag ${ }^{98}$.

\section{LITERATURVERZEICHNIS}

\section{Quellen}

Bruno z Querfurtu, Život svatého Vojtěcha, hg. u. übers. von Marie KYRALOVÁ. Praha 1996.

Codex diplomaticus et epistolarius Regni Bohemiae. Bd. 1, hg. von Gustav FRIEDRICH. Praha 1904-1907.

Codex diplomaticus et epistolarius Regni Bohemiae. Bd. 2, hg. von Gustav FRIEDRICH. Praha 1912.

Codex diplomaticus et epistolarius Regni Bohemiae. Bd. 3. Teil 1, hg. von Gustav FRIEDRICH. Praha 1942.

Codex diplomaticus et epistolarius Regni Bohemiae. Bd. 3. Teil 3, hg. von Gustav FRIEDRICH - Zdeněk KRISTEN - Jan BISTŘICKÝ. Olomouc 2000.

Codex diplomaticus et epistolarius Regni Bohemiae. Bd. 3. Teil 4, hg. von Jan BYSTǨICKÝ. Olomouc 2002.

Codex diplomaticus et epistolarius Regni Bohemiae. Bd. 4. Teil 1, hg. von Zbyněk SVITÁK - Helena KRMÍČKOVÁ - Jarmila KREJČÍKOVÁ. Praha 2006.

De conversione Bagoariorum et Carantanorum libellus., hg. von Wilhelm WATTENBACH, in: $M G H$ Scriptores (in Folio). Bd. 11: Historiae aevi Salici. Hannover 1854, S. 1-15.

Crescente fide Christiana. Recensio bavarica, hg. von Josef EMLER. Fontes rerum Bohemicarum. Bd. 1. Praha 1873, S. 183-190.

Fuit in provincia Boemorum, hg. von Václav CHALOUPECKÝ, Prameny 10. století Legendy Kristiánovy o sv. Václavu a sv. Ludmile. Praha 1939, S. 459-478.

Gumpoldi Mantuani episcopi Passio sancti Vencezlai martyris, hg. von Josef EMLER. Fontes rerum Bohemicarum. Bd. 1. Praha 1873, S. 146-166.

Die Chronik der Bohmen des Cosmas von Prag (Cosmae Pragensis Chronica Boemorum) (MGH Scriptores rerum Germanicarum. Nova series. Bd. 2), hg. von Berthold BRETZHOLZ. Berlin 1923.

Jana Kanaparia Život svatého Vojtěcha, hg. von Josef EMLER, in: Fontes rerum Bohemicarum. Bd. 1. Praha 1873, S. 235-265.

Kronika Neplachova, hg. von Josef EMLER, Fontes rerum Bohemicarum. Bd. 3. Praha 1882, S. 443-484.

Legenda Christiani. Vita et passio sancti Wenceslai et sancte Ludmile ave eius, hg. von Jaroslav LUDVÍKOVSKÝ. Praha 1978.

Letopis Kanovníka vyšehradského, hg. von Josef EMLER, in: Fontes rerum Bohemicarum. Bd. 1. Praha 1873 , S. 202-237.

Liber pontificalis. Bd. 1, hg. von Louis DUCHESNE. Paris 1886.

Libri Confirmationum. Bd. 1. Teil 1, hg. von František Antonín TINGL. Praha 1867.

Passio s. Vencezlai incipiens verbis Crescente fide christiana. Recensio bohemica, hg. von Jaroslav LUDVÍKOVSKÝ, in: Ders., Nově zjištěný rukopis legendy Crescente fide a jeho význam pro datování Kristiána, in: Listy filologicke 81 (1958), S. 56-67.

Proložní legenda o sv. Ludmile (Život sv. Lidmily), hg. von Josef KOLÁř, in: Fontes rerum Bohemicarum. Bd 1. Praha 1873, S. 123-124.

Regesta diplomatica nec non epistolaria Bohemiae et Moraviae. Bd. 2, hg. von Josef EMLER, Praha 1882.

Registra decimarum papalium čili registra desátků papeženských $z$ dioecezi Pražské, hg. von Václav Vladivoj TOMEK. Praha 1873.

Reliquiae Tabularum terae regni Bohemiae. Bd. 1, hg. von Josef EMLER. Praha 1899.

Thietmari Merseburgensis episcopi Chronicon (MGH Scriptores rerum Germanicarum. Nova series. Bd. 9), hg. von Robert HOLTZMANN. Berlin 1935.

Urkundenbuch der Stadt Saaz, hg. von Ludwig SCHLESINGER. Prag 1892.

Verše o utrpení svatého Vojtěcha [Versus de passione sancti Adalberti], hg. von Josef EMLER, in: Fontes rerum Bohemicarum. Bd. 1. Praha 1873, S. 313-334.

98 Sieh Tomáš VELÍMSKÝ, Česká nobilita doby Hroznatovy: od družinných elit raného středověku k vrcholně středověké pozemkové šlechtě, in: Minulostí západočeského kraje 52 (2017), s. 246-269. 


\section{Literatur}

Andrea BARTOŠKOVÁ, Dvorec hradského správce na Budči?: srovnání publikovaných závěrů s výpovědí terénní dokumentace, in: Archeologické rozhledy 56/2 (2004), S. 310-320.

Klára BENEŠOVSKÁ, Deset století architektury. Bd. 1: Architektura románská. Praha 2001.

Marie BLÁHOVÁ - Jan FROLÍK - Nada PROFANTOVÁ, Velké dějiny zemí Koruny české. Bd. 1. Praha/ Litomyšl 1999.

Zdeněk BOHÁČ, Topografický slovník k církevním dějinám předhusitských Čech. Pražský archidiakonát. Praha 2001.

Ivana BOHÁČOVÁ (Hg.), Stará Boleslav: přemyslovský hrad v raném středověku. Praha 2003.

Ivana BOHÁČOVÁ - Jaroslav ŠPAČEK, Třetí raně středověký kostel na akropoli hradiště v Staré Boleslavi, in: Archeologické rozhledy 46 (1994), S. 607-617.

Pavel BOLINA, Př́spěvek k interpretaci Kosmových desátkových údajů, in: ČČH 103 (2005), S. 828-860.

Ivan BORKOVSKÝ, Kostel Panny Marie na Pražském hradě, in: Památky archeologické 44 (1953), S. 129-198.

Dana CEJNKOVÁ, Archeologický výzkum ve starobrněnském klášteře, in: Forum Brunense: sborník prací Muzea města Brna. Brno 1992, S. 11-20.

Petr ČECH, Žatec v raném středověku (6. - počátek 13. století), in: Petr Holodňák - Ivana Ebelová (Hgg.), Žatec. Praha 2004, S. 71-78.

Zdeněk DRAGOUN, K stavebnímu vývoji kostela Stětí sv. Jana Křtitele v Hostivaři, in: Staletá Praha 20 (1990), S. 100-115.

Zdeněk DRAGOUN, Praha 885-1310: kapitoly o románské a raně gotické architektuře. Praha 2002.

Eduard DROBERJAR. Věk barbarů: České země a stěhování národi̊ z pohledu archeologie. Praha/Litomyšl 2005.

Hans Heinrich FEINE, Studien zum langobardisch-italischen Eigenkirchenrecht, in: Ulrich Stutz - Hans Erich Feine (Hgg.), Forschungen zu Recht und Geschichte der Eigenkirche. Aalen 1989 (ursprünglich als Studien zum langobardisch-italischen Eigenkirchenrecht. Teil 1, in: Zeitschrift der Savigny-Stiftung für Rechtsgeschichte, Kanonistische Abteilung 30 (1941), S. 1-95).

Johannes FRIED, Gnesen - Aachen - Rom: Otto III. und der Kult des hl. Adalbert: Beobachtungen zum älteren Adalbertsleben, in: Michael Borgolte (Hg.), Polen und Deutschland vor 1000 Jahren: die Berliner Tagung über den „Akt von Gnesen“. Berlin 2002, S. 235-279.

Jan FROLÍK, Kostel Panny Marie, in: Jan Frolík - Jana Maříková - Kubková (Hgg.), Nejstarší sakrální architektura Pražského hradu: výpověd’archeologických pramenů. Praha 2000, S. 17-95.

Soňa HENDRYCHOVÁ - Jan FROLÍK, Kostel sv. Václava v Žabonosech (okres Kolín) a jeho počátky, in: Archaeologia historica 41/1 (2016), S. 229-240.

Václav HRUBÝ, Tři studie $k$ české diplomatice. Brno 1936.

Karel KIBIC ml. - Filip VELÍMSKÝ, Př́spěvek ke stavební historii kostela sv. Jana Křtitele v Malíně: stavební vývoj, výsledky archeologického průzkumu, in: Průzkumy památek 15/1 (2008), S. 127-135.

Libor JAN, Hereditas, výsluha, kastelánie, in: ČMM 128 (2009), S. 461-472.

Libor JAN, Skrytý půvab „středoevropského modelu“, in: ČČH 105 (2007), S. 873-902.

Anežka MERHAUTOVÁ, Raně středověká architektura v Čechách. Praha 1971.

Anežka MERHAUTOVÁ - Dušan TŘEŠTíK, Románské umění v Čechách a na Moravě. Praha 1983.

Zdeněk MĚříNSKÝ, České země od př́chodu Slovanů po Velkou Moravu. Bd. 2. Praha 2006.

Věra NAŇKOVÁ, Slaný, in: Emanuel Poche (Hg.), Umělecké památky Čech. Bd. 3. Praha 1980, S. 336 f.

Jana NECHUTOVÁ, Latinská literatura českého středověku do roku 1400. Praha 2000.

Rostislav Nový - Jiří Sláma - Jana Zachová (Hgg.), Slavníkovci ve středověkém písemnictví. Praha 1987.

Václav NOVOTNÝ, České dějiny. Bd. 1. Teil 1. Praha 1912.

Rostislav NOVÝ, Diplomatické poznámky k donačním listinám českých klášterů a kapitul do konce 12. století, in: Studia mediaevalia Pragensia 2 (1991), S. 125-146.

Tomáš PETRÁČEK, Fenomén darovaných lidi v Čechách. Praha 2003.

Jiří PRAŽÁK, Nejstarší listina pražského kostela, in: Sborník archivních prací 10/1 (1960), S. 215-229.

Jiř́ PRAŽÁK, Privilegium pervetustum Boleslai, in: Ivan Hlaváček - Marie Bláhová (Hgg.), Milénium břevnovského kláštera (993-1993). Praha 1993, S. 13-24.

Antonín PROFOUS - Jan SVOBODA (Hgg.), Místní jména v Čechách: jejich vznik, pưvodní význam a změny, Bd. 4. Praha 1957. 
August SEDLÁČEK, Atlasy erbů a pečeti české a moravské šlechty, hg. von Vladimír Růžek. Bd. 5. Praha 2003.

Carla SFAMENI, Ville residenziali nell'Italia tardoantica. Bari 2007.

Zdeněk SMETÁNKA, Campus iuxta Suadow et iuxta Colasoy et iuxta Hriunatecz, (K otázce systému obdělávání polí v raném středověku), in: Studia mediaevalia Pragensia 2 (1991), S. 105-115.

Zdeněk SMETÁNKA, Legenda o Ostojovi. Praha 1992 (zweite erweiterte Ausgabe Praha 2004).

Petr SOMMER - Vojtěch VANĚK, Existe-t-il une architecture Slavníkienne?, in: Vaněk - Kroupa (Hgg.), Slavníkovci v českých dějinách, S. 20-34.

Petr SOMMER, Svatý Prokop: z počátků českého státu a církve. Praha 2007.

Ulrich STUTZ, Geschichte des kirchlichen Benefizialwesens von seinen Anfangen bis auf die Zeit Alexanders III., Berlin 1895.

Jindřich ŠEBÁNEK - Saša DUŠKOVÁ, Listina v českém státě doby Václava I. (Rozpravy ČSAV 73/10). Praha 1963.

Miloš ŠOLLE, Rotunda sv. Petra a Pavla na Budči, in: Památky archeologické 81 (1990), S. 140-207.

Jindřich TOMAS, Vrcholně středověké město a jeho rozvoj v předhusitské době, in: Petr Holodňák - Ivana Ebelová (Hgg.), Žatec. Praha 2004, S. 135 ff.

Dušan TŘEŠTíK, Počátky Přemyslovců: vstup Čechů do dějin (530-935). Praha 1997.

Dušan TŘEŠTíK, Proč byli vyvražděni Slavníkovci?, in: Vojtěch Vaněk - Jiří K. Kroupa (Hgg.), Slavníkovci v českých dějinách Praha 2006, S. 13-19.

Dušan TŘEŠTíK, Vznik Velké Moravy. Praha 2001.

Rudolf TUREK, Čechy na úsvitě dějin. Praha 1963.

Rudolf TUREK, Libice, knižecí hradisko 10. věku. Praha 1966-1968.

Josef VAJS, Sborník staroslovanských literárních památek o sv. Václavu a sv. Lidmile. Praha 1929.

Zdeněk VÁŇA, Přemyslovská Budeč: archeologický výzkum hradiště v letech 1972-1986. Praha 1995.

Vladimír VAVŘíNEK, Velká Morava mezi Byzancí a latinským Západem, in: Luděk Galuška - Pavel Kouřil - Zdeněk Měřínský (Hgg.), Velká Morava mezi Východem a Západem: sborník př́spěvků z mezinárodní vědecké konference, Uherské Hradiště, Staré Město 28. 9. - 1. 10. 1999. Brno 2001, S. 413-419.

Tomáš VELÍMSKÝ, Česká nobilita doby Hroznatovy: od družinných elit raného středověku k vrcholně středověké pozemkové šlechtě, in: Minulostí západočeského kraje 52 (2019), S. 246-269.

Tomáš VELÍMSKÝ, O královském podčeším, který toužil stát se stolníkem, in: Eva Doležalová - Petr Sommer (Hgg), Středověký kaleidoskop pro muže s hůlkou: věnováno Františku Šmahelovi kživotnímu jubileu. Praha 2014, S. 665-677.

Tomáš VELÍMSKÝ, K problematice pozemkové držby českých velmožů a družiníků v období 11.-12. století, in: Studia medaevalia Bohemica 1 (2009), S. 177-186.

Tomáš VELÍMSKÝ, Paní Bohatěj a její blízcí, in: Martin Nodl - Martin Wihoda (Hgg.), Šlechta, moc a reprezentace ve středověku. Praha 2007, S. 53-62.

Tomáš VELÍMSKÝ, Vzestupy a pády bílinských hradských správců, in: Ivana Boháčová - Petr Sommer (Hgg.), Středověká Evropa v pohybu: k poctě Jana Klápště. Praha 2014, S. 325-363.

Václav WAGNER, Kostel ve Vrbčanech, in: Jan Květ - Oldřich Blažíček (Hgg.), Cestami umění. Praha 1949, S. 48-56.

Martin WIHODA, Přemyslovská medievistika o sobě a sobě, in: ČMM 128 (2009), S. 447-460.

Martin WIHODA, Sázavský klášter v ideových souřadnicích českých dějin 11. věku, in: Sommer (Hg.), Svatý Prokop, Čechy a Evropa. Praha 2006, S. 237-250.

Susan WOOD, The Proprietary Church in the Medieval West. Oxford 2006.

Josef ŽEMLIČKA, Hmotné zabezpečení nejstarších benediktinských klášterů v Čechách, in: Petr Sommer (Hg.), Svatý Prokop, Čechy a Evropa. Praha 2006, S. 265-276.

Josef ŽEMLIČKA, K hodnověrnosti listiny Jana XV. pro klášter v Břevnově (31. V. 993), in: Ivan Hlaváček - Marie Bláhová (Hgg.), Milenium břevnovského kláštera (993-1993). Praha 1993, S. 25-39.

Josef ŽEMLIČKA, Královský ćínník Zbraslav a jeho dědictví (Vznik a rozklad jednoho feudálního dominia z první poloviny 13. století), in: Historická geografie 21 (1983), S. 117-132.

Josef ŽEMLIČKA, O „svobodné soukromosti“ pozemkového vlastnictví (K rozsahu a kvalitě velmožské držby v přemyslovských Čechách), in: ČČH 107 (2009), S. 269-308.

Josef ŽEMLIČKA, Počátky Čech královských. Praha 2002. 
Josef ŽEMLIČKA, Slaný - opožděné založení jednoho královského města, in: Zdeněk Kuchyňka (Hg.), Slaný: české město ve středověku: sborník př́spěvků z kolokvia k 700. výročí královského města Slaného. Kladno/Slaný 1997, S. 4-11.

Josef ŽEMLIČKA, Spor Přemysla Otakara I. s pražským biskupem Ondřejem, in: ČČH 29 (1981), S. 704-730.

Josef ŽEMLIČKA, Úcta svatého Gotharda v přemyslovských Čechách, in: Petr Kubín (Hg.), Světci a jejich kult ve středověku. Praha 2006, S. 345-349. 